\title{
To Eliminate the Muda in HPT in Panel Manufacturing
}

\author{
Sagar Sasane \\ Sr. Engineer, \\ Larsen \& Toubro ltd, Ahmednagar
}

\author{
Dilip Adhav \\ Deputy General Manager, \\ Larsen \& Toubro ltd, Ahmednagar
}

\begin{abstract}
The purpose of this paper is the focus on Muda improvement in an organization sustainability. The study used mixed method approach for Muda/waste identification, measurement and suggestions for controlling Muda/waste in the organization. This paper illustrates about Muda case study in Larsen and Toubro Company which produce Switchgear panel. Process improvement is a constant search for opportunities to improve the processes in the daily operations of the company and to enhance the relationships between processes. Waste elimination is one of the most effective ways to increase the profitability of any business. .Lean management is the way to achieve the perfect level of the organization through gradual and ongoing, which is characteristic for continuous improve approach, eliminate waste and losses in all aspect of business. To eliminate waste it is important to understand what waste is and where its exits. Value stream mapping and line balancing was the main tool used to identify the opportunities for various lean techniques. Due to implementation of Muda it increased the quality morale, delivery time and reduced the cost.
\end{abstract}

Keywords-Improve, Productivity, Muda, Lean

\section{INTRODUCTION}

Muda is a Japanese word meaning 'futility' uselessness, wastefulness and is a key concept in lean process thinking like Toyota Production System as one of the three types of deviation from optimal allocation of resources .waste reduction is an effective way to increase profitability. From an end customer point of view, Value added work is any activity that produces goods or provides a services for which a customer is willing to pay. Muda is any constraint or impediment that causes waste to occur. There are two type Company has made the project on colour coding of hand pallet truck in order for easy handling, care and rules have been implemented. As the L\&T company is multinational there is lot of work more than 47 pallet are been use. As various department use the pallet for different purpose.

\section{CASE STUDY}

The Muda concept was on hand pallet truck. The pallet truck are used for movement of material from one place to another. As L\&T is MNC Company it has many hand pallet truck. When the pallet goes for maintenance it create problem for which department the hand pallet truck belong to due to this lot of time is waste in identifying the pallet to which department it belong. To avoid this we have done colour coding technique to identify the hand pallet truck. of Muda 1-: non value adding but necessary for end customer .These are usually harder to eliminate because while classified as non-value adding, they may still be necessary. Muda2-: non value-adding and unnecessary for end customers. These contribute to waste incur hidden costs and should be eliminated.

There are seven type of waste Transport, Inventory, Motion, Waiting, Overproduction, over processing, Defects. Lean manufacturing proposes to improve factors that add value, and reduce what is wasted on all other factors. In manufacturing, waste is often very conservatively identified, which undercuts the potential for correction. The lean system was developed with reduced non value added activities so that greatly reduces the seven Muda. Lean manufacturing is one of the initiatives that many major business units in the world have been trying to adopt in order to remain competitive in globalization market. For example in daily life at home or in the family we have made the daily schedule for the body to make the right turns. When you are living your life in the home and in the workplace, Pokayoke, Kaizen, Lean, Value engineering, stream mapping all concept that you use. "Lean is the set of 'tools' that assist in the identification and steady elimination of waste (MUDA). To solve the problem of waste, Lean Manufacturing has several 'tools' at taking a very similar approach to other improvement methodologies.

The company has started looking into serious matter of Muda by using different engineering technique and logic in order to eliminate waste and to increase the production and growth of the company. The special focus is on quality and professional growth. By following this L\&T

The different department have different colour to identify their hand pallet truck due to this time is saved and work is done efficiently. The company has started looking into serious matter of Muda by using different engineering technique and logic in order to eliminate waste and to increase the production and growth of the company. The special focus is on quality and professional growth. By following this L\&T Company has made the project on colour coding of hand pallet truck in order for easy handling, care and rules have been implemented. As the L\&T company is multinational there is lot of work more than 50 pallet are been use. As various department use the pallet for different purpose. 


\subsection{ROOT CAUSE ANALYSIS}

The brainstorming technique is used for analysis of root cause that basically responsible for time wastes of operator.

Following root causes are observed

1. Unfortunate misplace of hand pallet truck.

2. Carelessness in operation.

3. Over usage

4. Time wastage

5. waiting

\begin{tabular}{|c|c|c|}
\hline Department & $\begin{array}{l}\text { Total HPT's } \\
\text { in Nos. }\end{array}$ & $\begin{array}{l}\text { Colour } \\
\text { code }\end{array}$ \\
\hline FABRICATION & 6 & \\
\hline PACKING & 11 & \\
\hline ODC & 7 & \\
\hline MATERIAL MOVEMENT & 2 & \\
\hline STORE & 5 & \\
\hline $\mathrm{R} \& \mathrm{D}$ & 2 & \\
\hline GIS & 2 & \\
\hline LINK SHOP & 1 & \\
\hline CMG & 1 & \\
\hline VCU SHOP & 1 & \\
\hline SQR & 1 & \\
\hline PLANT MAINTENANCE & 1 & \\
\hline OBSOLETE & 7 & \\
\hline Total & 47 & \\
\hline
\end{tabular}

Fig .1 Colour coding sheet of department.

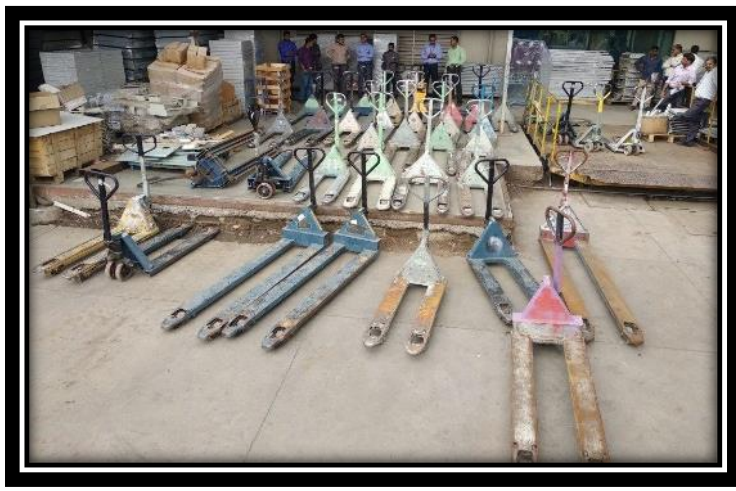

Fig 2. Uncoding hand pallet truck.

Benefit due to colour coding are as follow-

1. Unnecessary movement has been eliminated

The various department use the colour coding hand pallet it has become to find the department wise pallet easily and the time has been eliminated.

\section{It was possible to avoid wastage of time}

As the hand pallet are given specific colour coding so it has made possible easy to find them and time saving has become the important factor in an organization.

\section{Speed in work}

The waste movement has been eliminated and the work has been done fast. Due to colour coding the various department has got place for their pallet and requirement for own use has been made easy.

\section{Waiting}

In the past, the searching for hand pallet truck would take time, so waiting time in the process could create problem. But now colour coding eliminate the problem.

Many time when pallet broke out it goes to maintenance after maintenance which pallet should go for which department in this time was wasting. By using colour coding all this confusing process has been eliminated.

\section{5. over usage}

As a department has a special place to handle, where to put hand pallet trucks, this important issue can be eliminated by reducing extra labour required and the over processing.

\section{Use of skill}

Particularly for this coding more and more innovative ideas has been utilized for worker.

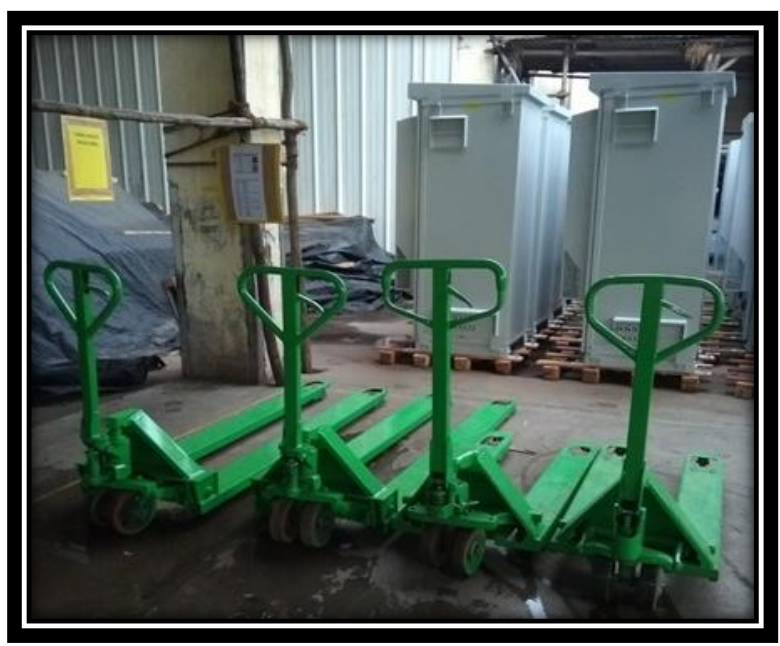

Fig 3. Colour coding Hand truck Pallet.

\section{RESULTS}

After implementing Muda in an organization for hand pallet truck the work has been done faster and the confusion process has been eliminated .Each department has done identification of their own hand pallet truck .It has made work done easy. 


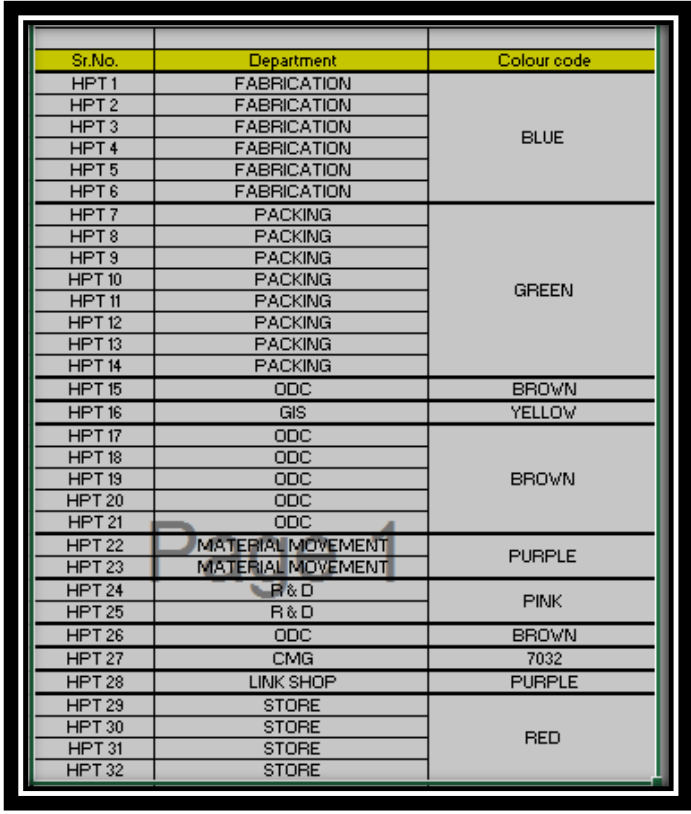

\begin{tabular}{|c|c|c|}
\hline HPT 33 & WCUSHOP & PURPLE \\
\hline HPT 34 & STORE & RED \\
\hline HPT35 & Gis & \begin{tabular}{|l} 
YELLOW \\
\end{tabular} \\
\hline HPT 36 & SQR & REED \\
\hline HPT 37 & PLANT MAINTENAANCE & \multirow{4}{*}{ GREEN } \\
\hline HPT 38 & PACKING & \\
\hline HPT39 & PACKING & \\
\hline HPT 40 & PACKING & \\
\hline HPT 41 & BEYONDREFPAIR & \\
\hline HPT 42 & BEYONDREPAIR & \\
\hline HPT 43 & BEYONDREPAIR & \\
\hline HPT 44 & BEYONDREPAIR & \\
\hline HPT 45 & BEYOND REPQAIR & \\
\hline HPT 46 & BEYONDREPAIR & \\
\hline HPT 47 & BEYOND REPAIR & \\
\hline
\end{tabular}

Fig 4. Hand pallet availability status

\section{CONCLUSION}

It is observed that after implementation of this Muda the process has become simple.

1. Time is saved.

2. Confusion has been eliminated.

3. Morale of operator increase.

4. Over usage reduce.

5. Easy identification.

6. Speed in work.

7. Productivity increased.

\section{REFERENCES}

[1] Kenkyusha's New Japanese-English Dictionary, 5th edition, 2003, Tokyo: Kenkyusha, p. 2530.

[2] Emiliani, Bob; Stec, David; Grasso, Lawrence; Stodder, James (2007). Better thinking, better results: case study and analysis of an enterprise-wide lean transformation (2nd ed.). Kensington, Conn: Center for Lean Business Management. ISBN 978-0-9722591-2-5.

[3] Kato, Isao; Smalley, Art (2011). Toyota Kaizen Methods: Six Steps to Improvement.

[4] Lean Enterprise Institute, Waste, accessed 3 February 2018

[5] 5. Sayer, Natalie; Williams, Bruce (2012). Lean For Dummies 2nd Edition.

[6] 6. Ohno, T. (1988), Toyota Production System: Beyond Large Scale Production, Productivity Press, and Portland, Oregon 